\title{
Właściwości stali S460M napawanej pod wodą metodą lokalnej komory suchej
}

\author{
Properties of S460M steel welded under water \\ by local cavity method
}

\section{Streszczenie}

W artykule przedstawiono wyniki badań próbek ze stali S460M napawanych pod wodą metodą lokalnej komory suchej. Pomiary twardości oraz analiza strukturalna wykazały, że dla określonych ilości wprowadzonego ciepła możliwe jest wykonanie złączy bez niezgodności spawalniczych. Stwierdzono formowanie się w pewnych warunkach pęknięć zimnych w SWC wywołanych procesami odprowadzania ciepła z materiału, które są charakterystyczne dla spawania metodą lokalnej komory suchej.

Słowa kluczowe: spawanie pod wodą; lokalna komora sucha; właściwości; struktura

\section{Abstract}

The article presents the results of non-destructive and destructive testing of S460M steel specimens with weld beads made underwater by local cavity method. Hardness measurements and structural analysis showed that for specific heat input value it is possible to make joints without welding imperfections. Under certain conditions cold cracks in the HAZ were formed. It was caused by the process of heat removal from the material, which is characteristic for under water welding by local cavity method.

Keywords: underwater welding; local cavity method; properties; structure

\section{Wprowadzenie}

Spawanie pod wodą znajduje najczęściej zastosowanie $w$ pracach remontowych oraz naprawczych $[1,2]$. Takie zadania mogą być realizowane na jednostkach pływających, platformach wiertniczych, rurociągach podwodnych czy konstrukcjach hydrotechnicznych, które ulegają awariom wskutek oddziaływania różnych czynników. Do najbardziej istotnych przyczyn awarii można zaliczyć: ubytki korozyjne wywołane środowiskiem pracy, kolizje z jednostkami pływającymi (np. uszkodzenia poszycia), błędy związane z konstrukcją oraz niewłaściwym wykonaniem (np. pęknięcia wywołane karbami technologicznymi), działania wojenne (celowe zniszczenie) [3]. Naprawy powinny zapewniać bezpieczną i bezawaryjną pracę w określonych ramach czasowych. W przypadku napraw z zastosowaniem spawania pod wodą stosowane są najczęściej dwie odmiany tego procesu: spawania mokre oraz spawanie suche $[4,5]$. Do podstawowych zalet spawania mokrego można zaliczyć stosunkowo niskie koszty oraz prostotę realizacji procesu (nieskomplikowane i niedrogie oprzyrządowanie), a do wad wysoki poziom wodoru dyfundującego w stopiwie (duża ilość pary wodnej w obszarze jarzenia się łuku), duże prędkości stygnięcia złączy spawanych związane ze złożonymi procesami odprowadzania ciepła (np. procesy wrzenia błonowego i pęcherzykowego), ograniczenie głębokości spawania do ok. $50 \mathrm{~m}[1,2,6]$. Z kolei spawanie suche umożliwia uzyskanie złączy spawanych o właściwościach zbliżonych do otrzymywanych podczas spawania na powietrzu. W tym przypadku podstawową wadą są bardzo wysokie koszty, co wynika z konieczności budowy specjalnych komór roboczych oraz infrastruktury (jednostka główna, jednostki pośrednie, śluzy itp.) $[7,8]$. Poszukiwania alternatywnych sposobów spawania pod wodą, które połączyłyby wysoką jakość złączy spawanych z ograniczeniem kosztów spawania doprowadziły do opracowania spawania pod wodą me-

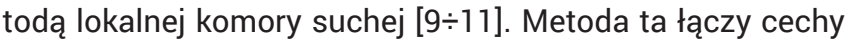
spawania mokrego oraz suchego. Idea spawania pod wodą metodą lokalnej komory suchej GMAW (MIG/MAG) została przedstawiona na rysunku 1. Gaz osłonowy podczas spawania lokalną komorą suchą spełnia podwójną rolę. Chroni jeziorko ciekłego metalu oraz dodatkowo usuwa wodę z obszaru spawania. Takie oddziaływanie wymusza stosowanie wyższej wartości natężenia przepływu gazu osłonowego w porównaniu do spawania metodą GMAW w środowisku powietrznym. Jego wartość jest uzależniona od głębokości spawania oraz wymiarów lokalnej komory suchej [12:14].

Do zalet spawania tą metodą można zaliczyć: ograniczenie prędkości stygnięcia oraz ilości wodoru dyfundującego w stopiwie do zakresu $10 \div 20 \mathrm{ml} / 100 \mathrm{~g}$, zmniejszenie kosztów spawania do poziomu spawania mokrego, możliwość spawania półautomatycznego i automatycznego,

Dr inż. Grzegorz Rogalski; dr inż. Dariusz Fydrych; dr hab. inż. Jerzy Łabanowski - Politechnika Gdańska.

Autor korespondencyjny/Corresponding author. grzrogal@pg.gda.pl 


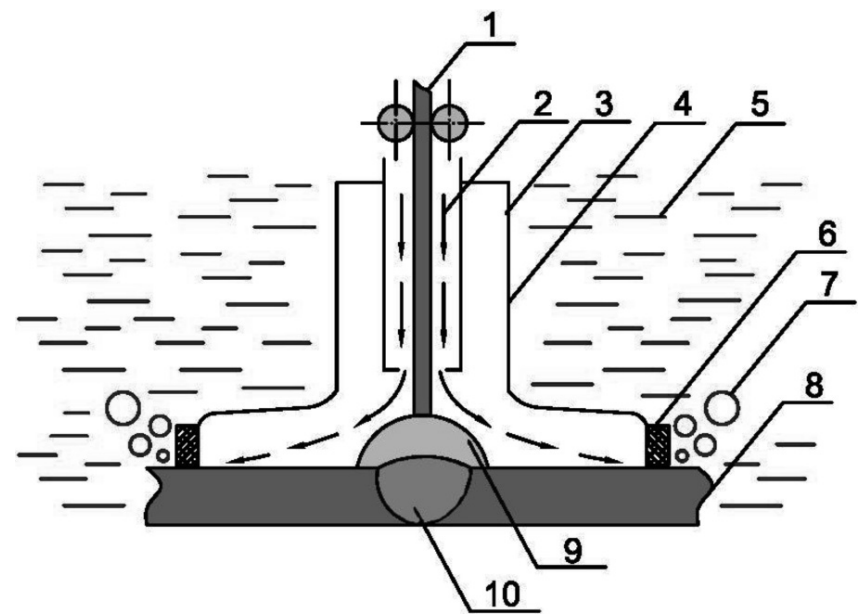

Rys. 1. Schemat spawania metodą lokalnej komory suchej. 1 - drut elektrodowy, 2 - gaz ochronny, 3 - dysza wewnętrzna, 4 - dysza zewnętrzna, 5 - woda, 6 - opaska elastyczna, 7 - pęcherzyki gazu, 8 - materiał spawany, 9 - łuk elektryczny, 10 - spoina

Fig. 1. Scheme of underwater welding by local cavity method: 1 - filler material (solid wire), 2 - shielding gas, 3 - internal nozzle, 4 - external nozzle, 5 - water, 6 - elastic band, 7 - gas bubbles, 8 - welded material, 9 - electric arc, 10 - weld

zwiększenie wydajności w porównaniu ze spawaniem ręcznym. Głównymi wadami opisywanej metody jest przede wszystkim brak możliwości obserwacji procesu spawania oraz powstawanie tzw. mokrego stanu powierzchni będącego skutkiem niedostatecznego osuszenia spawanych

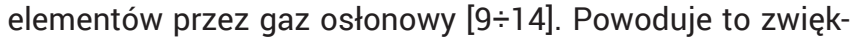
szoną skłonność stali do tworzenia pęknięć zimnych w porównaniu ze spawaniem w środowisku powietrznym [15].

\section{Badania własne}

Celem badań było określenie wpływu ilości wprowadzonego ciepła na twardość i strukturę napoin wykonanych na stali S460M pod wodą metodą lokalnej komory suchej.

Na podstawie analizy literatury [4] stwierdzono, że różnica pomiędzy czasami stygnięcia $t_{8 / 5}$ dla napoiny oraz spoiny wykonanej w złączu doczołowym z ukosowaniem na "V" jest nieznaczna (rys. 2). Można zatem przyjąć, że struktury i właściwości otrzymane w obrębie napoin odpowiadają strukturom w złączu doczołowym ze spoiną czołową.

\section{Plan badań}

Po analizie zmiennych istotnych właściwych dla procesu spawania pod wodą lokalną komorą suchą ustalono plan badań, który obejmował: wykonanie prób pozwalających na ustalenie ilości wprowadzonego ciepła dla ściegu graniowego i ściegów wypełniających, w tym warstwy

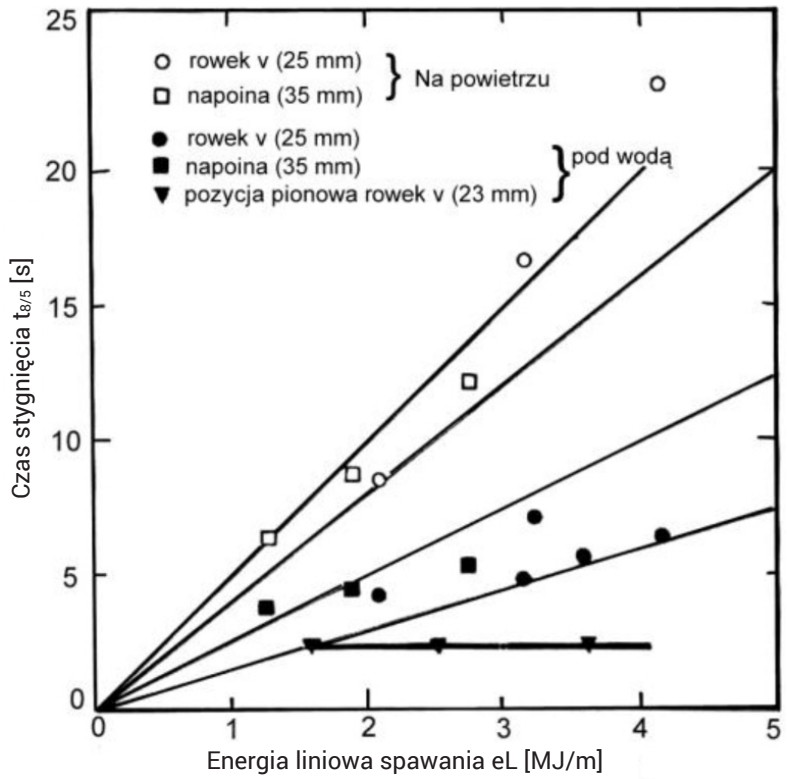

Rys. 2. Wpływ rodzaju złącza na wartość czasów stygnięcia t 8/5 $_{8}$ [4] Fig. 2. The influence of the type of welded joint on the cooling time $\mathrm{t}_{8 / 5}[4]$

licowej, wykonanie próbek napawanych, wykonanie badań nieniszczących (VT, PT) oraz niszczących (badania makroi mikroskopowe, pomiary twardości) zgodnie z odpowiednimi normami przedmiotowymi. Dla badań nieniszczących ustalono, że wykonane próbki muszą spełniać wymagania dla poziomu jakości B wg PN-EN ISO 5817 (Spawanie. Złącza spawane ze stali, niklu, tytanu i ich stopów (z wyjątkiem spawanych wiązką). Poziomy jakości wg niezgodności spawalniczych). Jako kryterium akceptacji dla pomiarów twardości przyjęto wartość 380HV10, co jest zgodne z normami PN-EN ISO 15614-1 (Specyfikacja i kwalifikowanie technologii spawania metali. Badanie technologii spawania. Część 1: Spawanie łukowe i gazowe stali oraz spawanie łukowe niklu i stopów niklu) oraz PN-EN ISO 15614-7 (Specyfikacja i kwalifikowanie technologii spawania metali. Badanie technologii spawania. Część 7: Napawanie) dla podgrupy materiałowej 2.1, do której zalicza się stal S460M.

\section{Materiały zastosowane do badań}

Do badań zastosowano blachę ze stali S460M (Wr nr: 1.8827) o wymiarach $12 \times 150 \times 250 \mathrm{~mm}$. Gatunek ten wysoką wytrzymałość zawdzięcza obróbce cieplno-plastycznej, która prowadzi do znacznego zmniejszenia rozmiaru ziarna $[16,17]$. Należy zaznaczyć, że w warunkach spawania na powietrzu stale uzyskane w ten sposób wykazują skłonność do pękania zimnego niż normalizowane stale o zbliżonych własnościach wytrzymałościowych [18]. Szczegółowe dane dla tego gatunku stali przedstawiono w PN-EN 10025-4

Tablica I. Skład chemiczny, równoważnik węgla CE oraz właściwości mechaniczne stali S460M Table I. Chemical composition, carbon equivalent CE and mechanical properties of S460M steel

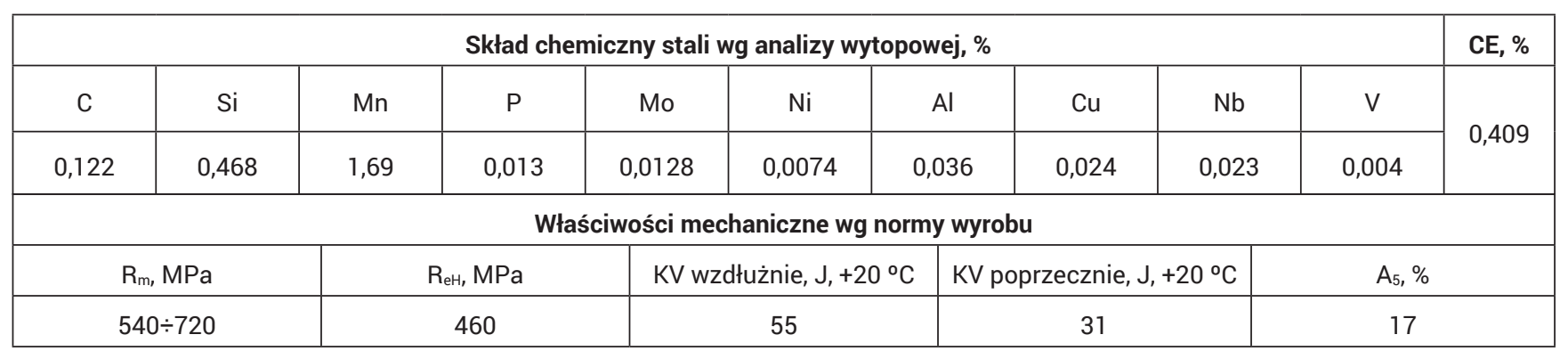


(Wyroby walcowane na gorąco ze stali konstrukcyjnych. Część 4: Warunki techniczne dostawy spawalnych stali konstrukcyjnych drobnoziarnistych po walcowaniu termomechanicznym). W tablicy I przedstawiono skład chemiczny zastosowanej stali wg analizy wytopowej oraz właściwości mechaniczne wg przywołanej normy wyrobu.

Do wykonania próbek zastosowano drut lity o oznaczeniu wg EN ISO 14341-A: G3Si1 oraz średnicy $\varphi=1,2 \mathrm{~mm}$. Spawanie drutem litym w osłonie gazu $\mathrm{CO}_{2}(\mathrm{C} 1 \mathrm{wg}$ PN-EN ISO 14175) jest procesem niskowodorowym [15], co w warunkach spawania pod wodą jest szczególnie istotne. Z tego względu w eksperymencie użyto gazu C1 $\left(100 \% \mathrm{CO}_{2}\right)$. Skład chemiczny oraz właściwości wytrzymałościowe materiału dodatkowego wg producenta przedstawiono $\mathrm{w}$ tablicy II.

Próbki wykonano metodą MAG, proces 135, z biegunowością DC+, w wodzie słodkiej na głębokości $400 \mathrm{~mm}$ na stanowisku do spawania i cięcia pod wodą na małych głębokościach, które znajduje się w Laboratorium Spawalnictwa Politechniki Gdańskiej [19]. Wydatek gazu osłonowego wynosił $35 \mathrm{l} / \mathrm{min}$. Wykonano 3 próbki oznaczone L1, L2 i L3 z rosnącą ilością wprowadzonego ciepła, $Q_{L}: 0,5 ; 0,8$ i 1,1 kJ/mm. Ilość wprowadzonego ciepła obliczono zgodnie z wytycznymi PN-EN 1011-1 (Spawanie. Zalecenia dotyczące spawania metali. Część 1: Ogólne wytyczne dotyczące spawania łukowego).

Tablica II. Skład chemiczny oraz właściwości mechaniczne materiału dodatkowego do spawania

Table II. Chemical composition and mechanical properties of filler material

\begin{tabular}{|c|c|c|c|c|}
\hline \multicolumn{5}{|c|}{ Skład chemiczny, \% } \\
\hline $\mathrm{C}$ & $\mathrm{Mn}$ & $\mathrm{Si}$ & $\mathrm{S}$ & $\mathrm{P}$ \\
\hline $0,06 \div 0,15$ & $1,40 \div 1,85$ & $0,80 \div 1,15$ & 0,025 & 0,025 \\
\hline \multicolumn{5}{|c|}{ Właściwości mechaniczne } \\
\hline $\mathrm{R}_{\mathrm{m}^{\prime}} \mathrm{MPa}$ & $\mathrm{R}_{\mathrm{e}^{\prime}} \mathrm{MPa}$ & $\mathrm{A}_{5^{\prime}} \%$ & $\mathrm{KV}, \mathrm{J}$ \\
\hline 500 & 420 & 22 & $27\left(-29^{\circ} \mathrm{C}\right)$ \\
\hline
\end{tabular}

\section{Wyniki badań}

\section{Wyniki badań nieniszczących i ich analiza}

Badania wizualne wykonano zgodnie z PN-EN ISO 17637 (Badania nieniszczące złączy spawanych. Badania wizualne złączy spawanych), a badania penetracyjne zgodnie z PNEN ISO 3452-1 (Badania nieniszczące. Badania penetracyjne. Część 1: Zasady ogólne). Żadne z badań nie wykazało występowania niezgodności spawalniczych, które są charakterystyczne dla zastosowanego procesu, czyli pęknięć powierzchniowych, podtopień ciągłych i lokalnych oraz porów. Świadczy to o stabilnie przylegającej komorze suchej do powierzchni płyt (brak wody w obszarze jarzenia się łuku) i właściwym doborze ilości wprowadzonego ciepła. Badane próbki spełniają założone kryteria akceptacji dla badań nieniszczących. Sklasyfikowano je na poziomie jakości B wg PN-EN ISO 5817.

\section{Wyniki badań niszczących i ich analiza}

Badania metalograficzne makroskopowe i mikroskopowe

Badania metalograficzne makro- i mikroskopowe wykonano zgodnie z PN-EN ISO 17639 (Badania niszczące spawanych złączy metali. Badania makroskopowe i mikroskopowe złączy spawanych). Próbkę do badań pobrano ze środkowej części płyty. Następnie została ona przygotowana przez etapowe szlifowanie papierami o odpowiedniej gradacji, a następnie polerowanie i trawienie odczynnikiem Nital. Badania mikroskopowe wykonano przy użyciu mikroskopu NEOPHOT 32, EPITYP 2. Założono, że dla badań makroskopowych niedopuszczalne są następujące niezgodności: pęknięcia oraz inne niezgodności płaskie, pojedyncze pęcherze gazowe oraz pory, gniazda pęcherzy. W przypadku badań mikroskopowych nie dopuszcza się występowania pęknięć. Na rysunku 3 przedstawiono wyniki badań makroskopowych.
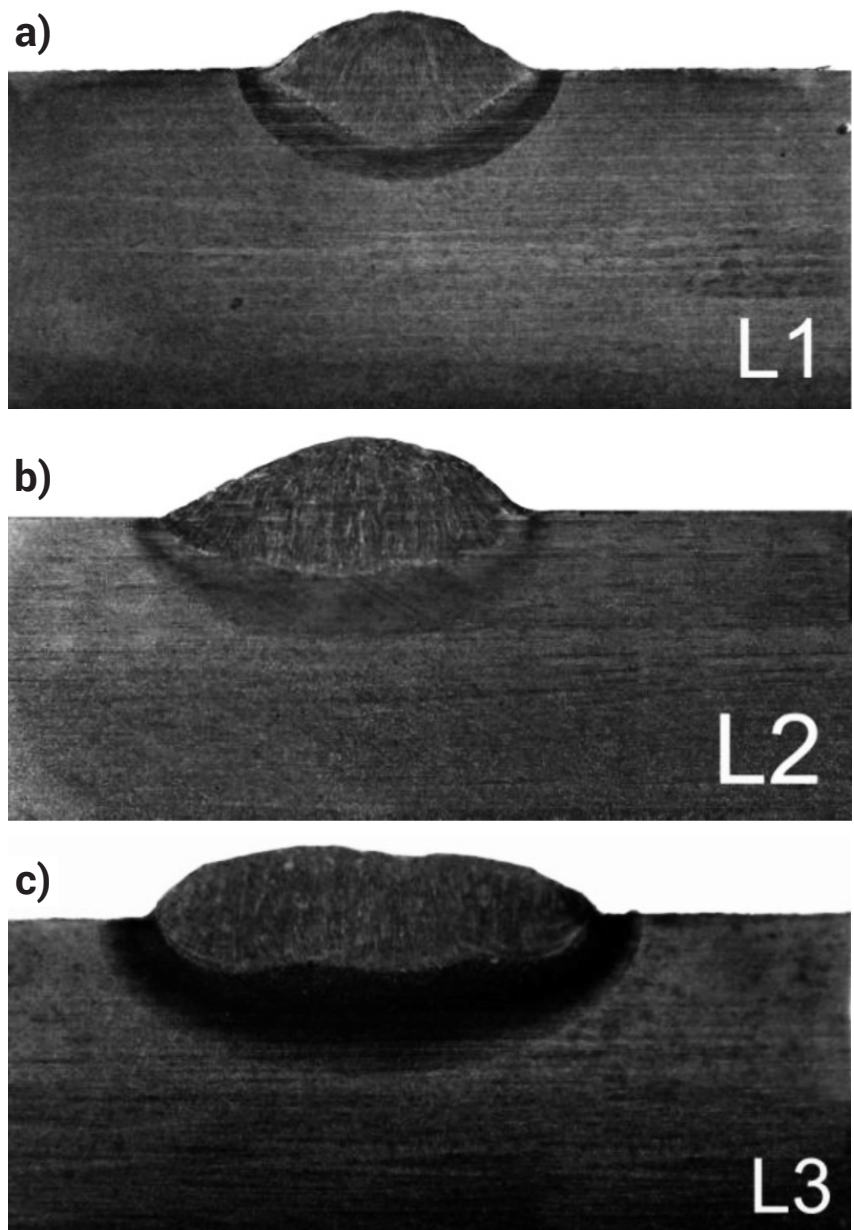

Rys. 3. Zgłady makroskopowe badanych próbek: a) L1 - 0,5 kJ/mm, b) $\mathrm{L} 2-0,8 \mathrm{~kJ} / \mathrm{mm}, \mathrm{c}) \mathrm{L} 3-1,1 \mathrm{~kJ} / \mathrm{mm}$

Fig. 3. Cross sections of specimens: a) L1 $-0,5 \mathrm{~kJ} / \mathrm{mm}$, b) $\mathrm{L} 2-0,8 \mathrm{~kJ} / \mathrm{mm}, \mathrm{c}) \mathrm{L} 3-1,1 \mathrm{~kJ} / \mathrm{mm}$

Próbka L1 (rys. 3a) charakteryzuje się symetryczną budową oraz regularną linią wtopienia. W przypadku próbek L2 oraz L3 (rys. 3b i 3c) szerokość napoiny jest większa od głębokości wtopienia i zwiększa się wraz z ilością wprowadzonego ciepła. Taka geometria może być właściwa do wykonywania ściegów wypełniających rowek spawalniczy oraz dla warstwy licowej. Dla wszystkich próbek zaobserwowano wyraźną SWC, a jej wielkość jest uzależniona od energii liniowej spawania. Nie stwierdzono występowania żadnych niezgodności spawalniczych, co świadczy o poprawnie wykonanym procesie. Wyniki badań metalograficznych mikroskopowych przedstawiono na rysunkach 4 i 5. Materiał rodzimy stali S460M charakteryzuje się strukturą ferrytyczną z niewielkim udziałem struktury perlitycznej w układzie pasmowym (rys. 4a). W spoinach badanych próbek zidentyfikowano strukturę dendrytyczną z układem kolumnowym ferrytu i quasiperlitu (rys. 4b). Dla zastosowanych powiększeń nie stwierdzono występowania defektów w materiale podstawowym (np. obszarów segregacji siarki) oraz niezgodności spawalniczych w spoinie (np. pęknięć). W obszarze przegrzania SWC (rys. 5a i 5b) wyraźnie 
zaznaczone są granice byłego austenitu, na tle których widoczny jest quasiperlit oraz iglaste struktury hartownicze, prawdopodobnie bainit. Na rysunku 5c i 5d przedstawiono pęknięcia występujące $w$ SWC $w$ pobliżu linii wtopienia dla próbki wykonanej $z Q_{L}=0,8 \mathrm{~kJ} / \mathrm{mm}$. W pozostałych próbkach (L1 - 0,5 kJ/mm; L3 - 1,1 kJ/mm) nie stwierdzono takich niezgodności. Wykryte pęknięcia to prawdopodobnie pęknięcia zimne, które są konsekwencją jednoczesnego występowania naprężeń spawalniczych, struktury hartowniczej oraz wodoru dyfundującego. Jednym z czynników, który wpływa na ryzyko formowania się takich niezgodności jest ilość wprowadzonego ciepła. Zwiększenie ilości wprowadzonego ciepła powoduje wydłużenie czasu $t_{8 / 5}$ [20], a więc uzyskane struktury powinny charakteryzować się niższą twardością i strukturą o mniejszym rozmiarze ziarna.
W analizowanym przypadku należy jednak uwzględnić stabilność jarzenia się łuku, która wpływa na mechanizmy związane z odprowadzaniem ciepła z elementów. Podczas spawania pod wodą metodą lokalnej komory suchej występuje wrzenie błonowe oraz pęcherzykowe. Przebieg tych procesów uzależniony jest m.in. od energii liniowej spawania oraz stabilności wprowadzania ciepła w materiał. Niestabilny łuk elektryczny powoduje stochastyczny przebieg wymienionych procesów, np. pęcherze charakterystyczne dla wrzenia błonowego zwiększają i zmniejszają swoją objętość prowadząc do lokalnego zwiększenia prędkości stygnięcia. Konsekwencją tego jest wzrost twardości do wartości odpowiadających strukturom hartowniczym. Takim mechanizmem można tłumaczyć występowanie pęknięć w próbce L2 wykonanej z Q $=0,8 \mathrm{~kJ} / \mathrm{mm}$.
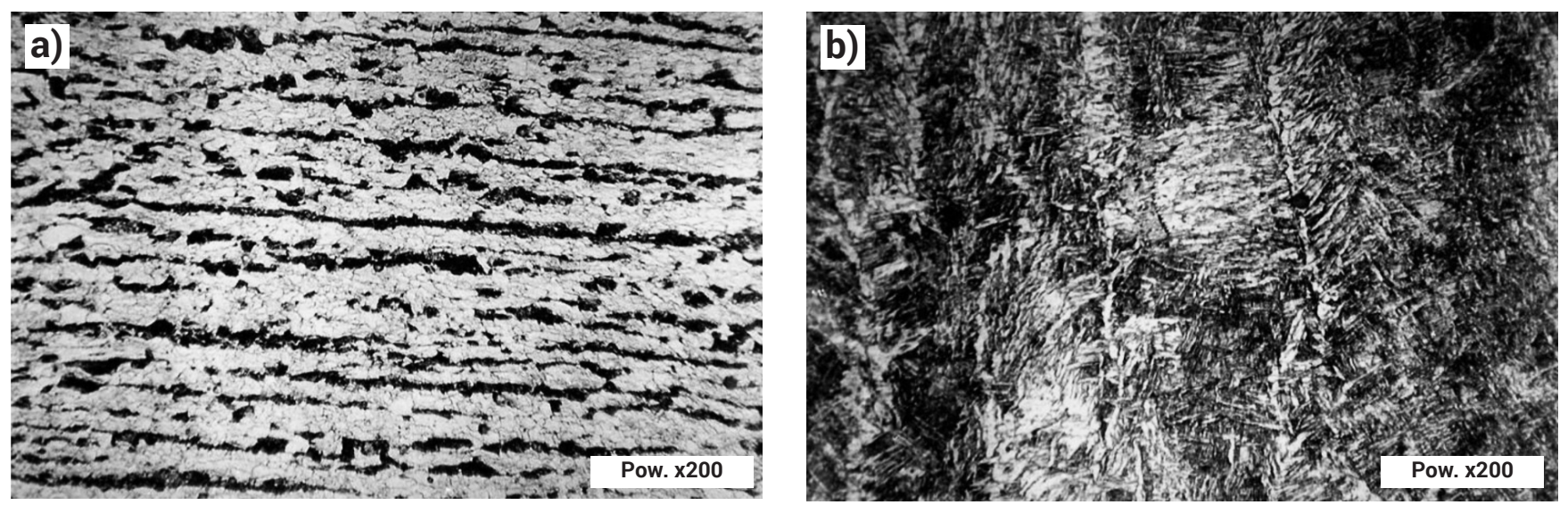

Rys. 4. Mikrostruktury badanych próbek: a) materiału rodzimego, b) spoiny. Trawienie Nital.

Fig. 4. Microstructures: a) base material, b) weld. Etching Nital.
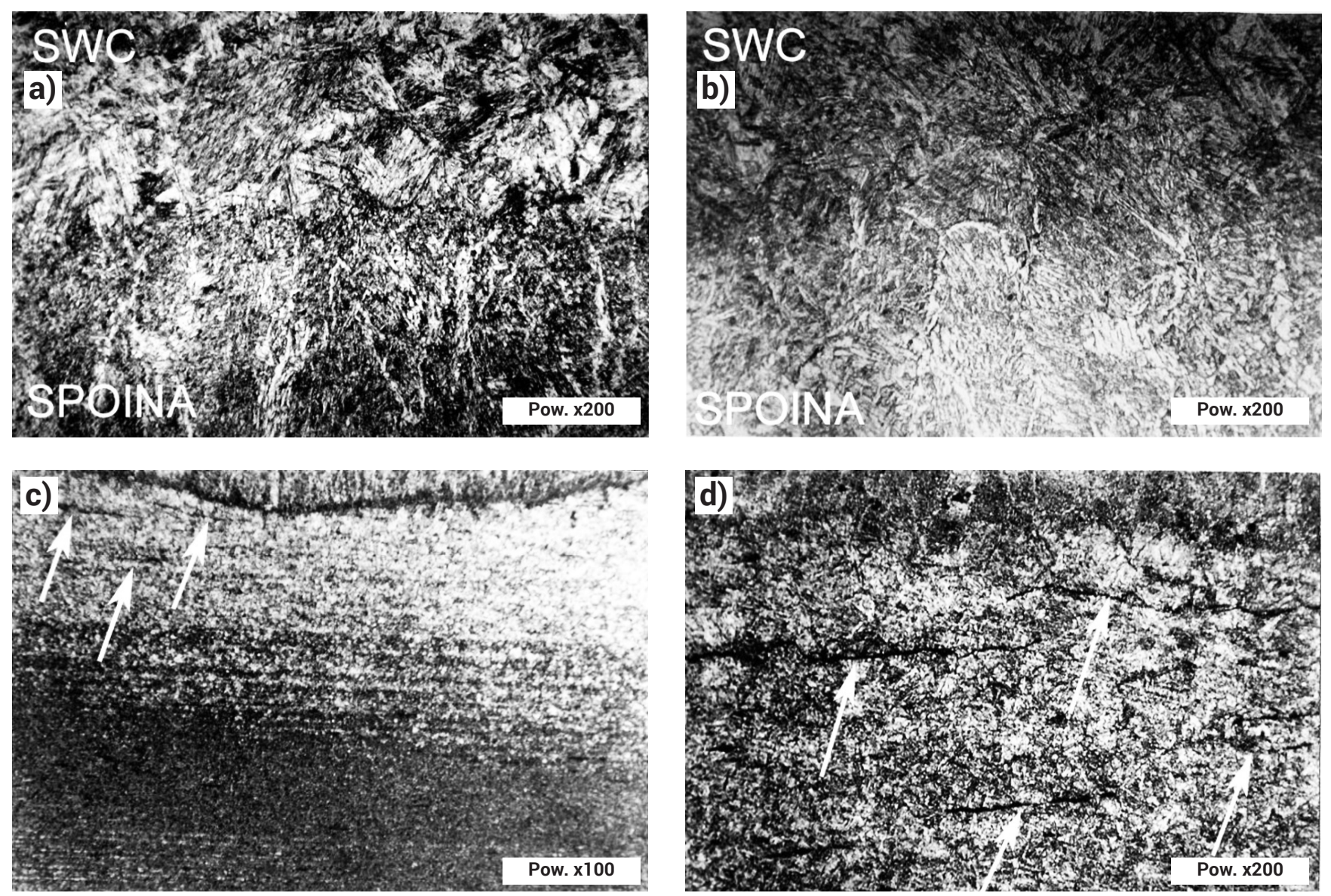

Rys. 5. Mikrostruktury obszaru SWC badanych próbek: a) L1, b) L3, c, d) L2

Fig. 5. Microstructure of HAZ of specimens: a) $L 1$, b) $L 3, c, d) L 2$ 
Pomiary twardości

Pomiary twardości wykonano na twardościomierzu HPO 250 metodą Vickersa wg PN-EN ISO 6507-1 (Metale. Pomiar twardości sposobem Vickersa. Metoda badań). Siła obciążająca wynosiła 98 N (HV10). W celu osiągnięcia większej dokładności punkty pomiarowe rozmieszczono zgodnie $z$ rysunkiem 6 . Wyniki badań przedstawiono w tablicy III.

Tablica III. Wyniki pomiarów twardości

Table III. Results of hardness measurements

\begin{tabular}{|c|c|c|c|c|}
\hline \multirow{3}{*}{$\begin{array}{l}\text { Miejsce } \\
\text { pomiaru }\end{array}$} & \multirow{3}{*}{$\begin{array}{c}\text { Punkty } \\
\text { pomiarowe }\end{array}$} & \multicolumn{3}{|c|}{ Oznaczenie próbki } \\
\hline & & L1 & L2 & L3 \\
\hline & & \multicolumn{3}{|c|}{ Wartości HV10 } \\
\hline MR & 1 & 176 & 173 & 156 \\
\hline MR & 2 & 118 & 168 & 168 \\
\hline MR & 3 & 180 & 180 & 178 \\
\hline MR & 4 & 183 & 212 & 189 \\
\hline MR & 5 & 194 & 186 & 194 \\
\hline MR & 6 & 183 & 177 & 187 \\
\hline SWC & 7 & 354 & 270 & 354 \\
\hline SWC & 8 & 373 & 360 & 354 \\
\hline SWC & 9 & 266 & 345 & 373 \\
\hline SWC & 10 & 264 & 339 & 266 \\
\hline SWC & 11 & 339 & 268 & 370 \\
\hline SWC & 12 & 287 & 281 & 268 \\
\hline LW & 13 & 354 & 238 & 247 \\
\hline LW & 14 & 348 & 197 & 325 \\
\hline LW & 15 & 317 & 238 & 230 \\
\hline LW & 16 & 325 & 370 & 351 \\
\hline LW & 17 & 357 & 370 & 446 \\
\hline $\mathrm{N}$ & 18 & 272 & 205 & 219 \\
\hline $\mathrm{N}$ & 19 & 287 & 202 & 218 \\
\hline $\mathrm{N}$ & 20 & 198 & 205 & 209 \\
\hline $\begin{array}{l}\text { MR - mat } \\
\text { SWC - str } \\
\text { LW - linia } \\
\text { N - napoi }\end{array}$ & $\begin{array}{l}\text { ał podstawo } \\
\text { wpływu cie } \\
\text { opienia }\end{array}$ & & & \\
\hline
\end{tabular}

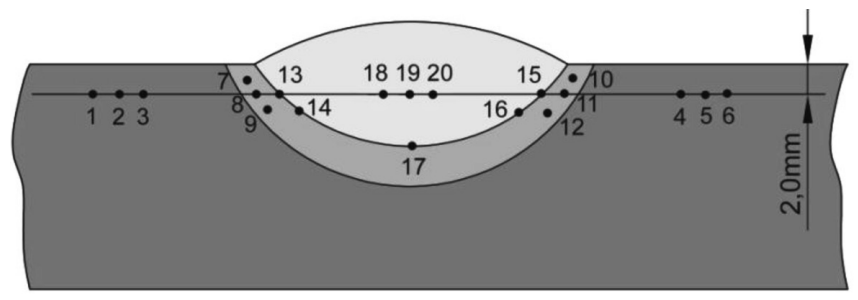

Rys. 6. Schemat pomiaru twardości w próbce napawanej: punkty 1-6 - materiał podstawowy (MR); punkty 7-12 - SWC; punkty 13-17 - LW (linia wtopienia); punkty $18-20$ - metal napoiny $(\mathrm{N})$

Fig. 6. Scheme of the hardness measurements in the sample with weld bead: points 1-6 - base material (MR); points 7-12 - HAZ; points 13-17 - fusion line (LW); points 18-20 - weld metal $(\mathrm{N})$

Materiał podstawowy charakteryzuje się twardością o wartościach typowych dla stali S460M. W obszarze SWC, poza linią wtopienia dla wszystkich badanych próbek nie odnotowano wzrostu twardości powyżej założonego kryterium akceptacji 380HV10. Najwyższe wartości (373HV10) stwierdzono w próbce L1 $(0,5 \mathrm{~kJ} / \mathrm{mm})$ i L3 $(1,1 \mathrm{~kJ} / \mathrm{mm})$. W przypadku pomiarów na linii wtopienia tylko w próbce L3 odnotowano jeden pomiar (punkt 17) powyżej założonego kryterium, który wynosił 446 HV10. Taki rozkład twardości odpowiada strukturom ujawnionym w badaniach metalograficznych mikroskopowych, np. struktura bainityczna na dnie linii wtopienia (próbka L2, punkt 17 - twardość 370HV10).

Uśredniając wyniki pomiaru twardości dla SWC oraz LW wyznaczono jej rozkład, który przedstawiono na rysunku 7. Wynika z niego, że wraz ze wzrostem ilości wprowadzonego ciepła twardość maleje, przy czym dla $Q_{L}=0,8 \mathrm{~kJ} / \mathrm{mm}$ oraz $\mathrm{Q}_{\mathrm{L}}=1,1 \mathrm{~kJ} / \mathrm{mm}$ średnia twardość w obszarze strefy wpływu ciepła jest taka sama i wynosi 297HV10. Taki rozkład jest prawdopodobnie związany z wydłużeniem czasu stygnięcia $t_{8 / 5}$ poprzez zwiększenie ilości wprowadzonego ciepła, co przedstawiono w pracy [20]. Szacowanie średniej twardości HV10 w SWC dla zmiennych istotnych ujętych w badaniach możliwe jest na podstawie równania (1) opisującego krzywą z rysunku 7.

$$
H V 10{ }_{S S S W C}=155,56 Q_{L}{ }^{2}-295,56 Q_{L}+434,71
$$

gdzie:

HV10 Śsswc -średnia twardość SWC, HV10,

$\mathrm{Q}_{\mathrm{L}}$ - ilość wprowadzonego ciepła, $\mathrm{kJ} / \mathrm{mm}$.

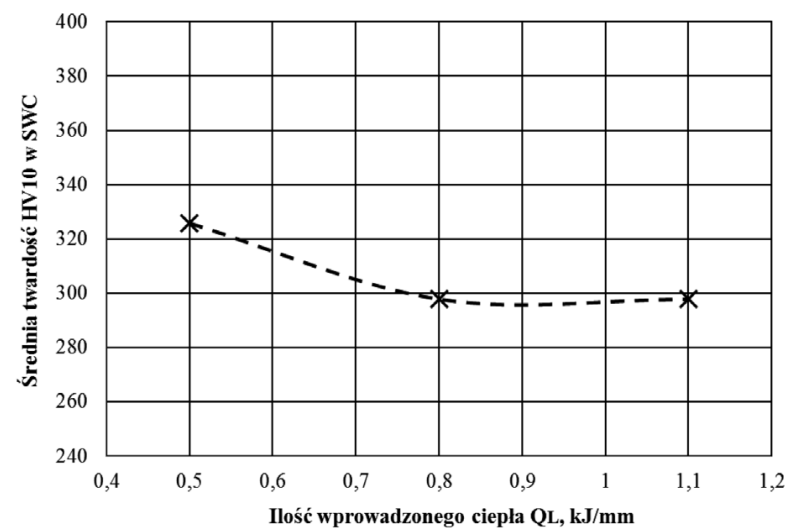

Rys. 7. Wpływ ilości wprowadzonego ciepła na średnią twardość w obszarze SWC

Fig. 7. Influence of heat input on average hardness of HAZ 


\section{Wnioski}

1. Określono wpływ ilości wprowadzonego ciepła na strukturę i twardość próbek ze stali S460M napawanych pod wodą metodą lokalnej komory suchej.

2. Badania nieniszczące VT oraz PT nie wykazały występowania niezgodności spawalniczych, co pozwoliło na sklasyfikowanie ich na poziomie jakości B wg PN-EN ISO 5817. Wyniki te zostały potwierdzone również badaniami makroskopowymi.

3. W próbce L2 wykonanej z $Q_{L}=0,8 \mathrm{~kJ} / \mathrm{mm}$ wykryto pęknięcia zimne w SWC. Ich tworzenie związane jest ze złożonymi procesami odprowadzania ciepła ze spawanych elementów.

4. Pomiary twardości potwierdziły wyniki badań metalograficznych mikroskopowych. Poza jednym punktem pomiarowym w próbce L3 uzyskane wartości są niższe od przyjętego kryterium akceptacji 380HV10.

5. Wyznaczono równanie pozwalające na szacowanie średniej twardości SWC dla próbek ze stali S460M wykonanych w warunkach zrealizowanych badań.

\section{Literatura}

[1] Fydrych D., Rogalski G, Łabanowski J.: Problems of underwater welding of higher-strength low alloy steels. Institute of Welding Bulletin 5/2014.

[2] Łabanowski J., Fydrych D., Rogalski G.: Underwater Welding - a review. Advances in Materials Science 3/2008.

[3] Fydrych D., Świerczyńska A., Rogalski G.: Effect of underwater wet we Iding conditions on the diffusible hydrogen content in deposited metal. Metallurgia Italiana 11/12/2015.

[4] Christensen N.: The metallurgy of underwater welding. Proceedings of the International Conference „Underwater Welding”, Trondheim, Norway 1983.

[5] Fydrych D., Świerczyńska A., Rogalski G., Łabanowski J.: Temper bead welding of S420G2+M steel in water environment. Advances in Materials Science 4/2016.

[6] Skorupa A., Bal M.: Wpływ środowiska wodnego na jakość połączeń spawanych pod wodą. Przegląd Spawalnictwa 3/1986.

[7] Fydrych D., Łabanowski J., Rogalski G., Haras J., Tomków J., Świerczyńska A., Jakóbczak P., Kostro Ł.: Weldability of S500MC steel in underwater conditions. Advances in Materials Science 2/2014.

[8] Fydrych D., Rogalski G., Świerczyńska A., Łabanowski J.: Ocena przydatności komercyjnych elektrod otulonych do spawania mokrego pod woda z wykorzystaniem analizy skupień. Przegląd Spawalnictwa 10/2015.

[9] Rogalski G., Łabanowski J., Fydrych D., Tomków J.: Bead-on-plate weIding on S235JR steel by underwater local dry chamber process. Polish Maritime Research. 2/2014

[10] Fydrych D., Rogalski G.: Effect of underwater local cavity welding method conditions on diffusible hydrogen content in deposited metal. Welding International 3/2013.
[11] Rogalski G., Fydrych D., Łabanowski J.: Ocena możliwości spawania pod wodą drutem proszkowym metodą lokalnej komory suchej. Biuletyn Instytutu Spawalnictwa 5/2012.

[12] Rogalski G., Fydrych D.: Wpływ parametrów spawania pod woda na twardość złączy. Prace Naukowe Politechniki Warszawskiej. Mechanika 230/2010.

[13] Rogalski G., Łabanowski J.: Effect of welding parameters for a local dry cavity underwater welding process on the structure and properties of joints. Welding International 7/2015.

[14] Fydrych D., Rogalski G., Prokop K.: Badania warunków spawania pod wodą metodą lokalnej komory suchej. Przegląd Spawalnictwa 9/2014.

[15] Fydrych D.: Wpływ warunków spawania na skłonność do tworzenia pęknięć zimnych przy spawaniu pod wodą. Praca doktorska, Politechnika Gdańska, Gdańsk 2005.

[16] Górka J.: Przemiany strukturalne stali S700MC w warunkach oddziaływania symulowanych cykli cieplnych spawania. Przegląd Spawalnictwa $10 / 2015$.

[17] Fydrych D., Tomków J., Rogalski G., Łabanowski J.: Weldability of S460ML high strength low alloy steel in underwater conditions. Applied Mechanics and Materials 838/2016.

[18] Brózda J., Zeman M., Łomozik M.: Walcowana termomechanicznie stal S460ML i jej spawalność. Biuletyn Instytutu Spawalnictwa 5/1999.

[19] Fydrych D., Łabanowski J., Rogalski G.: Weldability of high strength steels in wet welding conditions. Polish Maritime Research 2/2013.

[20] Rogalski G.: Wyznaczanie czasów stygnięcia przy spawaniu pod wodą metoda lokalnej komory suchej. Praca doktorska, Politechnika Gdańska, Gdańsk 2006. 